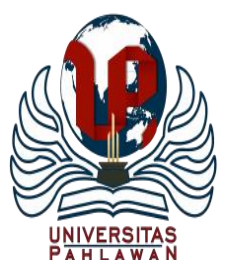

Edukatif : Jurnal Ilmu Pendidikan Volume 3 Nomor 4 Tahun 2021 Halm 1997 - 2007

EDUKATIF: JURNAL ILMU PENDIDIKAN

Research \& Learning in Education

https:/ledukatif.org/index.php/edukatif/index

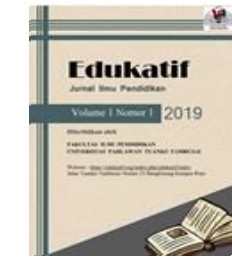

\title{
Pengaruh Pelaksanaan Supervisi Akademik dan Motivasi Kerja Guru terhadap Kinerja Guru Sekolah Dasar
}

\author{
Wardatul Adibah $^{1 凶}$, Suhartono ${ }^{2}$, Rais Hidayat ${ }^{3}$ \\ Universitas Terbuka, Indonesia ${ }^{1}$ \\ Universitas Sebelas Maret, Indonesia ${ }^{2}$ \\ Universitas Pakuan, Indonesia ${ }^{3}$ \\ E-mail : wardatul.adibah73@ gmail.com ${ }^{1}, \underline{\text { suhartono@fkip.uns.ac.id }}{ }^{2}$, rais72rais@gmail.com $^{3}$
}

\begin{abstract}
Abstrak
Penelitian ini bertujuan untuk: (1) menganalisis pengaruh supervisi akademik kepala sekolah berpengaruh terhadap kinerja guru SD Negeri se-Kecamatan Pejagoan; (2) menganalisis pengaruh motivasi kerja berpengaruh terhadap kinerja guru SD Negeri se-Kecamatan Pejagoan; (3) menganalisis pengaruh supervisi akademik dan motivasi kerja berpengaruh terhadap kinerja Guru SD Negeri se-Kecamatan Pejagoan. Populasi dalam penelitian ini adalah adalah semua guru sekolah negeri pada jenjang SD yang bertugas diwilayah Kecamatan Pejagoan Kabupaten Kebumen, yang berjumlah 161 orang dan sampel yang digunakan adalah 114 dengan teknik Random Sampling. Pengumpulan data dilakukan dengan metode angket. Uji validitas dengan teknik analisis Product Moment dan uji reliabilitas menggunakan Alpha Cronbach. Uji persyaratan analisis data menggunakan uji normalitas, linearitas, dan multikolinieritas. Pengujian hipotesis menggunakan regresi linier sederhana dan regresi linier berganda. Hasil penelitian ini menunjukkan: (1) Terdapat pengaruh positif antara supervisi akademik terhadap kinerja guru dengan nilai signifikansi 0,000 lebih kecil dari 0,05; (2) Terdapat pengaruh positif antara motivasi kerja terhadap kinerja guru dengan nilai signifikansi 0,000 lebih kecil dari 0,05 ; (3) terdapat pengaruh positif antara supervisi akademik dan motivasi kerja terhadap kinerja guru dengan Nilai $\mathrm{R}^{2}$ atau R Square sebesar 0,581 menunjukan bahwa variabel supervisi akademik dan motivasi kerja mempengaruhi variabel kinerja guru sebesar 58,1\% sedangkan sisanya 41,9\% dipengaruhi oleh variabel lain.
\end{abstract}

Kata Kunci: Supervisi Akademik, Motivasi Kerja, dan Kinerja Guru.

\begin{abstract}
This study aims to: (1) analyze the effect of the principal's academic supervision on the performance of elementary school teachers in Pejagoan District; (2) analyze the effect of work motivation on the performance of elementary school teachers in Pejagoan District; (3) analyzing the effect of academic supervision and work motivation on the performance of State Elementary School teachers in Pejagoan District. The population in this study were all public school teachers at the elementary level who served in the Pejagoan District, Kebumen Regency, totaling 161 people and the sample used was 114 with the Random Sampling technique. Data was collected by using the questionnaire method. Validity test using Product Moment analysis technique and reliability test using Cronbach Alpha. Test the data analysis requirements using normality, linearity, and multicollinearity tests. Hypothesis testing using simple linear regression and multiple linear regression. The results of this study indicate: (1) There is a positive influence between academic supervision on teacher performance with a significance value of 0.000 less than 0.05; (2) There is a positive influence between work motivation on teacher performance with a significance value of 0.000 less than 0.05 ; (3) there is a positive influence between academic supervision and work motivation on teacher performance with an $R 2$ or $R$ Square value of 0.581 indicating that the variables of academic supervision and work motivation affect teacher performance variables by $58.1 \%$ while the remaining $41.9 \%$ is influenced by other variables.
\end{abstract}

Keywords: Principal Management, Teacher Performance and Learning Interest.

Copyright (c) 2021 Wardatul Adibah, Suhartono, Rais Hidayat

$\triangle$ Corresponding author

Email : wardatul.adibah73@gmail.com

DOI : https://doi.org/10.31004/edukatif.v3i4.1049

ISSN 2656-8063 (Media Cetak)

ISSN 2656-8071 (Media Online) 
1998 Pengaruh Pelaksanaan Supervisi Akademik dan Motivasi Kerja Guru terhadap Kinerja Guru Sekolah Dasar - Wardatul Adibah, Suhartono, Rais Hidayat

DOI: https://doi.org/10.31004/edukatif.v3i4.1049

\section{PENDAHULUAN}

Pendidikan merupakan kegiatan manusia yang dilakukan secara terus menerus dengan tujuan menjadi lebih baik dalam kelangsungan hidup bangsa. Pendidikan berkualitas sangat diperlukan dalam usaha untuk kemajuan bangsa dan negara. Muslich (2011) menyatakan pendidikan merupakan pembudayaan diri seseorang dan masyarakat membentuk orang dan masyarakat yang beradab. Bangsa yang besar ditentukan oleh sumber daya manusianya, dan tingkat pendidikan masyarakat sangat menentukan sumber daya manusia. Tingkat pendidikan di masyarakat sangat dipengaruhi oleh guru. Salah satu komponen kinerja guru adalah kegiatan pembelajaran. Keberhasilan pembelajaran sangat ditentukan oleh kinerja guru.

Apabila diamati di lapangan, terutama di SD Negeri se-Kecamatan Pejagoan, sebagian guru sudah menunjukkan kinerja yang maksimal di dalam menjalankan tugas dan fungsinya sebagai pendidik, pengajar dan pelatih, tetapi sebagian guru menunjukkan kinerja kurang baik, buktinya mereka datang ke sekolah tidak tepat waktu yang lebih parahnya lagi guru tersebut sampai di sekolah tidak mengajar, mereka duduk dengan santainya sambil membaca koran, mengajar sambil mainan Handphone. Dengan motivasi kerja dan kinerja guru seperti itu, tentunya secara tidak langsung akan mempengaruhi kinerja guru secara keseluruhan. Ukuran kinerja guru dapat terlihat dari rasa tanggung jawabnya dalam menjalankan amanah, profesi yang diembannya, rasa tanggung jawab moral di pundaknya. Sesuai dengan pengamatan dan wawancara di lapangan, guru yang kinerjanya maksimal karena termotivasi dalam bekerja dan sering komunikasi, disupervisi oleh kepala sekolah, sedangkan guru yang kurang maksimal kinerjanya diperlukan peningkatan kompetensi dan komunikasi yang baik dengan kepala sekolah.

Menurut Gusti (2012) menyatakan bahwa motivasi kerja guru tidak memiliki pengaruh yang signifikan terhadap kinerja guru. Korelasi yang positif namun tidak signifikan ini menunjukan tinggi rendahnya motivasi kerja guru tidak berpengaruh terhadap kinerja guru. Begitu pula hasil terhadap supervisi kepala sekolah yang tidak signifikan berpengaruh terhadap kinerja guru. Pada penelitian Rismawan (2015) menyatakan untuk supervisi kepala sekolah memiliki pengaruh yang signifikan terhadap kinerja guru. Dari penelitian tersebut terdapat perbedaan akan hasil yang diperoleh. Hasil yang ada menunjukkan adanya pengaruh yang signifikan dan yang tidak signifikan. Inkonsistensi terhadap kesimpulan hasil penelitian tersebut menjadi salah satu alasan bagi penulis untuk mengadakan penelitian kemudian mengkaji dan menganalisis data yang diperoleh.

Mulyasa (2015) menyatakan "Para pegawai (guru) akan bekerja dengan sungguh-sungguh apabila memiliki motivasi yang tinggi. Apabila memiliki motivasi yang positif, ia akan memperlihatkan minat, mempunyai perhatian, dan ingin ikut serta dalam suatu tugas atau kegiatan". Sesuai dengan pendapat tersebut, guru yang masih kurang berhasil dalam mengajar dikarenakan mereka kurang termotivasi untuk mengajar sehingga berdampak terhadap menurunnya produktivitas atau kinerja guru. Untuk itu diperlukan peran kepala sekolah untuk memotivasi para guru untuk meningkatkan kinerjanya.

Guru dituntut memiliki kemampuan dan keterampilan sebagai bagian dari kompetensi profesionalisme guru. Agar tugas sebagai guru terlaksana dengan baik maka guru mutlak memiliki kompetensi sesuai standar yang ada. Guru profesional perlu meningkatkan kompetensinya melalui kegiatan penataran, pelatihan maupun kesempatan belajar ke jenjang pendidikan yang lebih tinggi dan pembinaan secara terus menerus secara berkesinambungan. Namun perlu juga diperhatikan kesejahteraan guru seperti gaji yang sesuai, pemberian insentif dengan tetap meningkatkan disiplin, pemberian motivasi, pemberian bimbingan melalui supervisi sehingga memungkinkan kinerja guru meningkat.

Beberapa guru memiliki motivasi kerja yang rendah. Keadaan ini dapat dibuktikan dengan jam kerja guru yang tidak sesuai ketentuan 37,5 jam per minggu. Kehadiran guru di sekolah sering terlambat. Indikasi masih kurang optimalnya motivasi kerja guru juga dapat dilihat dari beberapa guru yang meninggalkan tugas mengajar, membiarkan jam kosong begitu saja tanpa memberikan tugas pengganti. Selain itu banyak guru yang pangkat atau golongannya sampai menjelang pensiun berkutat di IV A bahkan lebih dari delapan tahun 
1999 Pengaruh Pelaksanaan Supervisi Akademik dan Motivasi Kerja Guru terhadap Kinerja Guru Sekolah Dasar - Wardatul Adibah, Suhartono, Rais Hidayat

DOI: https://doi.org/10.31004/edukatif.v3i4.1049

tidak bisa naik pangkat. Guru golongan IV A tidak mampu meningkatkan karirnya karena tidak termotivasi untuk membuat karya ilmiah, tidak melengkapi perangkat pembelajaran sebagai wujud kompetensi profesionalnya.

Kegiatan supervisi kepala sekolah dan motivasi kerja guru akan berpengaruh secara psikologis terhadap guru dan guru akan bekerja dengan suka rela yang akhirnya dapat membuat produktivitas kerja guru menjadi meningkat. Tetapi jika pelaksanaan supervisi dan motivasi kepala sekolah tidak berpengaruh maka guru akan bekerja karena terpaksa dan kurang bergairah yang ditunjukkan oleh sikap-sikap yang negatif hal ini mengakibatkan produktivitas kerja guru menjadi turun. Dampak permasalahan hasil pendidikan yang yang tidak baik tidak dapat dibiarkan terus menerus karena berakibat tidak baik pada di sekolah. Oleh karena itu penulis tertarik untuk melakukan penelitian lebih lanjut untuk mengetahui supervisi pembelajaran kepala sekolah dan motivasi kerja terhadap kinerja guru di SD Negeri se-Kecamatan Pejagoan. Berdasarkan hasil penelitian terdahulu dan literatur serta kajian yang telah diuraikan, beberapa penelitian terdahulu semuanya dilaksanakan di lingkungan SMP maupun di SMA, variabel yang digunakan terkait, supervisi, kepemimpinan kepala sekolah, motivasi kerja dan kinerja guru, setelah dianalisis dan ditelaah ternyata belum ada penelitian secara spesifik meneliti tentang supervisi akademik dan motivasi kerja terhadap kinerja guru di lingkungan Sekolah Dasar. Disinilah nilai kebaruan atau novelty dalam tulisan ini.

\section{METODE PENELITIAN}

Jenis penelitian ini adalah penelitian kuantitatif menurut Emzir (2015: 29) penelitian kuantitatif adalah penelitian yang menggunakan asumsi filosofis tuntutan pengetahuan postpositivisme, yang akan menggunakan strategi penelitian survei dan eksperimen. Populasi dalam penelitian ini adalah semua guru sekolah negeri pada jenjang Sekolah Dasar (SD) yang bertugas diwilayah Kecamatan Pejagoan Kabupaten Kebumen,yang berjumlah 161orang. Berdasarkan jumlah populasi sebanyak 161 guru SD Negeri seKecamatan Pejagoan diambil 114 guru dengan teknik random sampling sebagai sampelnya dengan taraf kesalahan 5\% berdasarkan tabel yang dikembangkan oleh Isaac dan Michael (Sugiyono, 2017).

Instrumen yang digunakan dalam penelitian ini yaitu angket atau kuesioner. Angket atau kuesioner digunakan untuk mengukur variabel-variabel yaitu supervisi akademik dan kinerja guru. Angket dalam penelitian ini menggunakan skala Likert dengan 4 alternatif jawaban yaitu selalu, sering, kadang-kadang dan tidak pernah. Uji validitas dengan teknik analisis Product Moment dan uji reliabilitas menggunakan Alpha Cronbach. Uji persyaratan analisis data menggunakan uji normalitas, linearitas, dan multikolinearitas. Pengujian hipotesis menggunakan regresi sederhana dan regresi berganda.

\section{HASIL DAN PEMBAHASAN PENELITIAN}

\section{Variabel Supervisi Akademik}

Data pada variabel supervisi akademik diperoleh melalui angket yang bersifat tertutup dengan jumlah item sebanyak 19 butir soal. Skor yang digunakan dalam angket tersebut adalah 1 sampai 4, sehingga berdasarkan skor tersebut maka variabel supervisi akademik memiliki rentang skor 19 sampai 76. Dari angket yang disebarkan kepada 114 responden menunjukkan bahwa variabel supervisi akademik diperoleh skor tertinggi sebesar 72 dan skor terendah sebesar 49.

\section{Variabel Motivasi Kerja}

Data pada variabel motivasi kerja diperoleh melalui angket yang bersifat tertutup dengan jumlah item sebanyak 17 butir soal. Skor yang digunakan dalam angket tersebut adalah 1 sampai 4, sehingga berdasarkan skor tersebut maka variabel kompetensi guru memiliki rentang skor 17 sampai 68. Dari angket yang 
2001 Pengaruh Pelaksanaan Supervisi Akademik dan Motivasi Kerja Guru terhadap Kinerja Guru Sekolah Dasar - Wardatul Adibah, Suhartono, Rais Hidayat

DOI: https://doi.org/10.31004/edukatif.v3i4.1049

Berdasarkan hasil di atas diperoleh nilai Deviation from Linearity Sig. adalah 0,242 lebih besar dari 0,05. Maka dapat disimpulkan bahwa ada hubungan linier secara signifikan antara variable Supervisi Akademik (X1) dengan variable Kinerja Guru (Y).

Tabel 3. Hasil Uji Linearitas Variabel X2 dengan Y

\begin{tabular}{|c|c|c|c|c|c|c|c|}
\hline \multicolumn{8}{|c|}{ ANOVA Table } \\
\hline & & & $\begin{array}{l}\text { Sum of } \\
\text { Squares }\end{array}$ & Df & $\begin{array}{l}\text { Mean } \\
\text { Square }\end{array}$ & $\mathrm{F}$ & Sig. \\
\hline \multirow{5}{*}{$\begin{array}{l}\text { Kinerja Guru } \\
\text { * Motivasi } \\
\text { Kerja }\end{array}$} & Between & (Combined) & 3979.466 & 20 & 198.973 & 6.328 & .000 \\
\hline & Groups & Linearity & 3327.820 & 1 & 3327.820 & 105.837 & .000 \\
\hline & & $\begin{array}{l}\text { Deviation from } \\
\text { Linearity }\end{array}$ & 651.646 & 19 & 34.297 & 1.091 & .373 \\
\hline & Within C & oups & 2924.192 & 93 & 31.443 & & \\
\hline & Total & & 6903.658 & 113 & & & \\
\hline
\end{tabular}

Berdasarkan hasil di atas diperoleh nilai Deviation from Linearity Sig. adalah 0,373 lebih besar dari 0,05. Maka dapat disimpulkan bahwa ada hubungan linier secara signifikan antara variable Motivasi Kerja (X1) dengan variable Kinerja Guru (Y).

Pengujian multikolinearitas bertujuan untuk menguji apakah model regresi ditemukan adanya pengaruh antar variabel bebas. Model regresi yang baik seharusnya tidak terjadi pengaruh di antara variabel bebas. Berdasarkan data yang sudah dihitung menggunakan program SPSS 25.0 diperoleh hasil sebagai berikut.

Tabel 4. Hasil Uji Multikolinearitas

\begin{tabular}{|c|c|c|c|c|c|c|c|c|}
\hline \multicolumn{9}{|c|}{ Coefficients $^{\mathrm{a}}$} \\
\hline \multirow{2}{*}{\multicolumn{2}{|c|}{ Model }} & \multicolumn{2}{|c|}{$\begin{array}{l}\text { Unstandardized } \\
\text { Coefficients }\end{array}$} & \multirow{2}{*}{$\begin{array}{c}\text { Standardized } \\
\text { Coefficients } \\
\text { Beta }\end{array}$} & \multirow[t]{2}{*}{$\mathrm{T}$} & \multirow[t]{2}{*}{ Sig. } & \multicolumn{2}{|c|}{$\begin{array}{c}\text { Collinearity } \\
\text { Statistics }\end{array}$} \\
\hline & & $\mathrm{B}$ & Std. Error & & & & Tolerance & VIF \\
\hline \multirow[t]{3}{*}{1} & (Constant) & 13.080 & 5.368 & & 2.437 & .016 & & \\
\hline & $\begin{array}{l}\text { Supervisi } \\
\text { Akademik }\end{array}$ & .594 & .116 & .439 & 5.130 & .000 & .516 & 1.939 \\
\hline & $\begin{array}{l}\text { Motivasi } \\
\text { Kerja }\end{array}$ & .535 & .118 & .389 & 4.548 & .000 & .516 & 1.939 \\
\hline
\end{tabular}

a. Dependent Variable: Kinerja Guru

Berdasarkan tabel di atas dapat diketahui bahwa nilai variance inflation factor (VIF) kedua variabel yaitu Supervisi Akademik sebesar 1,939 dan variable motivasi kerja sebesar 1,939. Kedua VIF dari kedua variable tersebut lebih dari 0,10 sehingga dapat disimpulkan bahwa antara variabel independen tidak terjadi persoalan multikolinearitas.

\section{Persamaan Regresi Linier Sederhana dari Supervisi Akademik terhadap Kinerja Guru}

Perhitungan persamaan regresi linier X1 dan Y menggunakan uji SPSS 25.0 tertera pada tabel berikut:

Tabel 5. Hasil Analisis Rergresi Linier X1 terhadap Y

\begin{tabular}{|c|c|c|c|c|c|c|}
\hline \multicolumn{7}{|c|}{ ANOVA $^{a}$} \\
\hline \multicolumn{2}{|l|}{ Model } & $\begin{array}{l}\text { Sum of } \\
\text { Squares }\end{array}$ & Df & $\begin{array}{l}\text { Mean } \\
\text { Square }\end{array}$ & $\mathrm{F}$ & Sig. \\
\hline \multirow[t]{3}{*}{1} & Regression & 3474.407 & 1 & 3474.407 & 113.475 & $.000^{\mathrm{b}}$ \\
\hline & Residual & 3429.251 & 112 & 30.618 & & \\
\hline & Total & 6903.658 & 113 & & & \\
\hline \multicolumn{7}{|c|}{ a. Dependent Variable: Kinerja Guru } \\
\hline \multicolumn{7}{|c|}{ b. Predictors: (Constant), Supervisi Akademik } \\
\hline
\end{tabular}


2002 Pengaruh Pelaksanaan Supervisi Akademik dan Motivasi Kerja Guru terhadap Kinerja Guru Sekolah Dasar - Wardatul Adibah, Suhartono, Rais Hidayat

DOI: https://doi.org/10.31004/edukatif.v3i4.1049

Tabel 6. Hasil Perhitungan Nilai B Persamaan Regresi

\begin{tabular}{|c|c|c|c|c|c|c|}
\hline \multicolumn{7}{|c|}{ Coefficients $^{\mathrm{a}}$} \\
\hline \multirow[b]{2}{*}{ Model } & & $\begin{array}{r}\text { Unstan } \\
\text { Coef }\end{array}$ & $\begin{array}{l}\text { ndardized } \\
\text { ficients }\end{array}$ & $\begin{array}{c}\text { Standardized } \\
\text { Coefficients }\end{array}$ & \multirow[b]{2}{*}{$\mathrm{T}$} & \multirow[b]{2}{*}{ Sig. } \\
\hline & & B & Std. Error & Beta & & \\
\hline \multirow[t]{2}{*}{1} & (Constant) & 20.658 & 5.533 & & 3.733 & .000 \\
\hline & $\begin{array}{l}\text { Supervisi } \\
\text { Akademik }\end{array}$ & .961 & .090 & .709 & 10.652 & .000 \\
\hline
\end{tabular}

Berdasarkan hasil dari pengolahan data menggunakan SPSS 25.0 maka analisisnya sebagai berikut:

a) Hipotesis

(1) Hipotesis Nol (H0)

Tidak ada pengaruh yang signifikan antara supervisi akademik terhadap kinerja guru SD se-

Kecamatan Pejagoan Kabupaten Kebumen

(2) Hipotesis Alternatif (Ha)

Terdapat pengaruh yang signifikan antara supervisi akademik terhadap kinerja guru SD se-

Kecamatan Pejagoan Kabupaten Kebumen

b) Kriteria Pengambilan Keputusan

Nilai signifikansi $\leq 0,05$ berarti $\mathrm{H} 0$ ditolak dan Ha diterima

Nilai signifikansi $>0,05$ berarti H0 diterima dan Ha ditolak

c) Pengambilan Keputusan

Berdasarkan Tabel ANOVA pada kolom sig. diperoleh nilai signifikansi sebesar 0,000. Hal ini menunjukkan bahwa H0 ditolak dan Ha diterima. Karena nilai signifikansi 0,000 lebih kecil dari 0,05 . Dapat disimpulkan bahwa ada pengaruh yang signifikan antara supervisi akademik terhadap kinerja guru SD se-Kecamatan Pejagoan Kabupaten Kebumen. Selanjutnya data dimasukkan dalam persamaan regresi linier sederhana yaitu $\hat{Y}=a+b X$ dilihat pada tabel coefficients pada Unstandardized Coefficients. Persamaan regresi sebagai berikut.

$\hat{\mathrm{Y}}=\mathrm{a}+\mathrm{bX}$

$\hat{\mathrm{Y}}=20,658+0,961 \mathrm{X}$

Persamaan regresi tersebut dapat dijelaskan sebagai berikut:

(a) Konstanta sebesar 20,658 berarti jika X nilainya 0, maka kinerja guru (Y) bernilai 20,658.

(b) Koefisien regresi variabel supervisi akademik (X) sebesar 0,961. Artinya jika supervisi akademik mengalami kenaikan 1\%, maka kinerja guru (Y) akan mengalami peningkatan sebesar $96,1 \%$. Koefisien tersebut bernilai positif yang berarti terjadi hubungan positif antara supervisi akademik dengan kinerja guru. Semakin baik supervisi akademik, semakin baik pula kinerja guru.

\section{Persamaan Regresi Linier Sederhana dari Motivasi Kerja Guru terhadap Kinerja Guru}

Perhitungan persamaan regresi linier X2 dan Y menggunakan uji SPSS 25.0 tertera pada tabel berikut.

Tabel 7. Hasil Analisis Rergresi Linier X2 terhadap Y

\begin{tabular}{lcccccc}
\hline \multicolumn{6}{c}{ ANOVA $^{\mathbf{a}}$} & \\
Sum of & & Mean & & \\
Model & & Squares & df & Square & F & Sig. \\
\hline 1 & Regression & 3327.820 & 1 & 3327.820 & 104.232 & $.000^{\mathrm{b}}$ \\
\hline
\end{tabular}




\begin{tabular}{|c|c|c|c|c|c|c|}
\hline & Residual & 357 & 5.838 & 31.927 & & \\
\hline & Total & 690 & 3.658 & & & \\
\hline \multicolumn{7}{|c|}{ a. Dependent Variable: Kinerja Guru } \\
\hline \multicolumn{7}{|c|}{ b. Predictors: (Constant), Motivasi Kerja } \\
\hline \multicolumn{7}{|c|}{ Tabel 8. Hasil Perhitungan Nilai B Persamaan Regresi } \\
\hline \multicolumn{7}{|c|}{ Coefficients $^{\mathbf{a}}$} \\
\hline \multirow[b]{2}{*}{ Model } & & $\begin{array}{r}\text { Unstan } \\
\text { Coeff }\end{array}$ & $\begin{array}{l}\text { dardized } \\
\text { icients }\end{array}$ & $\begin{array}{l}\text { Standardized } \\
\text { Coefficients }\end{array}$ & $\mathrm{T}$ & Sig. \\
\hline & & $\mathrm{B}$ & Std. Error & Beta & & \\
\hline \multirow[t]{2}{*}{1} & (Constant) & 25.847 & 5.266 & & 4.908 & .000 \\
\hline & $\begin{array}{l}\text { Motivasi } \\
\text { Kerja }\end{array}$ & .954 & .093 & .694 & 10.209 & .000 \\
\hline
\end{tabular}

a. Dependent Variable: Kinerja Guru

Berdasarkan hasil pengolahan data dengan SPSS versi 25.0, data dapat dianalisis sebagai berikut:

a) Hipotesis

(1) Hipotesis Nol (H0)

Tidak ada pengaruh yang signifikan antara motivasi kerja guru terhadap kinerja guru SD se-

Kecamatan Pejagoan Kabupaten Kebumen

(2) Hipotesis Alternatif (Ha)

Ada pengaruh yang signifikan antara motivasi kerja guru terhadap kinerja guru SD se-

Kecamatan Pejagoan Kabupaten Kebumen.

b) Kriteria Pengambilan Keputusan

Nilai signifikansi $\leq 0,05$ Maka H0 ditolak Ha diterima.

Nilai signifikansi > 0,05 Maka H0 diterima Ha ditolak.

c) Pengambilan Keputusan

Berdasarkan Tabel ANOVA pada kolom sig. diperoleh nilai signifikansi sebesar 0,000. Hal ini menunjukkan bahwa H0 ditolak dan Ha diterima. Karena nilai signifikansi lebih kecil dari 0,05 yaitu 0,000 . Dari hasil tersebut, dapat disimpulkan bahwa ada pengaruh yang signifikan antara motivasi kerja guru terhadap kinerja guru SD se-Kecamatan Pejagoan Kabupaten Kebumen.

Selanjutnya data dimasukkan ke dalam persamaan regresi linier sederhana yaitu $\hat{Y}=a+b X$ dapat dilihat pada tabel coefficients pada Unstandardized Coefficients B. Persamaan regresi sebagai berikut.

$\hat{\mathrm{Y}}=\mathrm{a}+\mathrm{bX}$

$\hat{\mathrm{Y}}=25,847+0,954 \mathrm{X}$

Persamaan regresi di atas dapat dijelaskan sebagai berikut.

(a) Konstanta sebesar 25,847 yang artinya jika X2 nilainya 0, maka kinerja guru (Y) nilainya adalah 25,847.

(b) Koefisien regresi variabel motivasi kerja guru (X2) sebesar 0,954. Artinya jika motivasi kerja guru mengalami kenaikan 1\%, maka kinerja guru (Y) akan mengalami peningkatan 95,4\% . Dengan asumsi variabel independen lain nilainya tetap. Koefisien bernilai positif artinya terdapat hubungan positif antara motivasi kerja guru dengan kinerja guru. Semakin baik motivasi kerja guru semakin baik pula kinerja guru.

\section{Hasil Analisis Regresi Berganda}

Perhitungan persamaan regresi berganda X1 dan X2 terhadap Y berdasarkan pengolahan SPSS 25.0 tertera pada tabel berikut. 
2004 Pengaruh Pelaksanaan Supervisi Akademik dan Motivasi Kerja Guru terhadap Kinerja Guru Sekolah Dasar - Wardatul Adibah, Suhartono, Rais Hidayat

DOI: https://doi.org/10.31004/edukatif.v3i4.1049

Tabel 9. Hasil Analisis Rergresi Linier X1 dan X2 terhadap Y

\begin{tabular}{|c|c|c|c|c|c|c|}
\hline \multicolumn{7}{|c|}{ ANOVA $^{\mathrm{a}}$} \\
\hline \multicolumn{2}{|l|}{ Model } & $\begin{array}{l}\text { Sum of } \\
\text { Squares }\end{array}$ & Df & $\begin{array}{l}\text { Mean } \\
\text { Square }\end{array}$ & $\mathrm{F}$ & Sig. \\
\hline \multirow[t]{3}{*}{1} & Regression & $4013 .($ & 77 & 2006.539 & 77.052 & .000 \\
\hline & Residual & 2890. & 111 & 26.041 & & \\
\hline & Total & 6903.6 & 113 & & & \\
\hline \multicolumn{7}{|c|}{ a. Dependent Variable: Kinerja Guru } \\
\hline \multicolumn{7}{|c|}{ b. Predictors: (Constant), Motivasi Kerja, Supervisi Akademik } \\
\hline \multicolumn{7}{|c|}{ Tabel 10. Hasil Perhitungan Nilai B Persamaan Regresi } \\
\hline \multicolumn{7}{|c|}{ Coefficients $^{\mathrm{a}}$} \\
\hline & & \multicolumn{2}{|c|}{$\begin{array}{l}\text { Unstandardized } \\
\text { Coefficients }\end{array}$} & $\begin{array}{l}\text { tandardized } \\
\text { Coefficients }\end{array}$ & & \\
\hline \multicolumn{2}{|c|}{ Model } & $\mathrm{B}$ & Std. Error & Beta & $\mathrm{t}$ & Sig. \\
\hline \multirow[t]{3}{*}{1} & (Constant) & 13.080 & 5.368 & & 2.437 & .016 \\
\hline & $\begin{array}{l}\text { Supervisi } \\
\text { Akademik }\end{array}$ & .594 & .116 & .439 & 5.130 & .000 \\
\hline & $\begin{array}{l}\text { Motivasi } \\
\text { Kerja }\end{array}$ & .535 & .118 & .389 & 4.548 & .000 \\
\hline
\end{tabular}

Berdasarkan pengolahan data menggunakan SPSS 25.0, maka dapat dianalisis sebagai berikut.

1) Hipotesis

a) Hipotesis $\mathrm{Nol}(\mathrm{H} 0)$

Tidak ada pengaruh yang signifikan antara supervisi akademik dan motivasi kerja guru secara bersama-sama terhadap kinerja guru SD se-Kecamatan Pejagoan Kabupaten Kebumen.

b) Hipotesis Alternatif (Ha)

Ada pengaruh yang signifikan antara supervisi akademik dan motivasi kerja guru terhadap kinerja guru SD se- Kecamatan Pejagoan Kabupaten Kebumen.

2) Kriteria Pengambilan Keputusan

Nilai signifikansi $\leq 0,05$ Maka H0 ditolak Ha diterima.

Nilai signifikansi > 0,05 Maka H03 diterima Ha3 ditolak.

3) Pengambilan Keputusan

Berdasarkan Tabel ANOVA pada kolom sig. diperoleh nilai signifikansi sebesar 0,000. Hal ini menunjukkan bahwa $\mathrm{H} 0$ ditolak dan Ha diterima. Karena nilai signifikansi lebih kecil dari 0,05 yaitu 0,000. Dari hasil tersebut, dapat disimpulkan bahwa ada pengaruh yang signifikan antara supervisi akademik dan motivasi kerja guru terhadap kinerja guru SD se- Kecamatan Pejagoan Kabupaten Kebumen.

Langkah selanjutnya adalah memasukkan data ke dalam persamaan regresi linier berganda yaitu $\hat{Y}=a+b 1 X 1+b 2 X 2$ dapat dilihat pada tabel coefficients pada Unstandardized Coefficients $\mathrm{B}$ : constant. Persamaan regresi sebagai berikut.

$\hat{\mathrm{Y}}=\mathrm{a}+\mathrm{b} 1 \mathrm{X} 1+\mathrm{b} 2 \mathrm{X} 2$

$\hat{\mathrm{Y}}=13,080+0,594 \mathrm{X} 1+0,535 \mathrm{X} 2$

Persamaan regresi di atas dapat dijelaskan sebagai berikut.

(1) Konstanta sebesar 13,080 yang artinya jika nilai X1 dan X2 adalah 0, maka kinerja guru (Y) nilainya 13,080 .

(2) Koefisien regresi variabel supervisi akademik (X1) sebesar 0,594 yang artinya jika supervisi akademik mengalami kenaikan 1\%, maka kinerja guru (Y) akan mengalami kenaikan sebesar 
59,4\% dengan asumsi variabel lain bernilai tetap. Koefisien bernilai positif artinya terjadi hubungan yang positif antara supervisi akademik dengan kinerja guru. Semakin baik supervisi akademik, semakin baik pula kinerja guru.

(3) Koefisien regresi variabel motivasi kerja guru (X2) sebesar 0,535 yang artinya jika motivasi kerja guru mengalami kenaikan 1\%, maka kinerja guru (Y) akan mengalami kenaikan sebesar 53,5\% dengan asumsi variabel lain bernilai tetap. Koefisien bernilai positif artinya terjadi hubungan yang positif antara motivasi kerja guru dengan kinerja guru. Semakin baik motivasi kerja guru semakin baik pula kinerja guru.

\section{Pengaruh Supervisi Akademik terhadap Kinerja Guru}

Berdasarkan hasil analisis regresi pada Tabel ANOVA dalam kolom sig. diperoleh nilai signifikansi sebesar 0,000. Hal ini menunjukkan bahwa H0 ditolak dan Ha diterima. Karena nilai signifikansi 0,000 lebih kecil dari 0,05. Dapat disimpulkan bahwa ada pengaruh yang signifikan antara supervisi akademik terhadap kinerja guru SD se-Kecamatan Pejagoan Kabupaten Kebumen. Hasil penelitian ini mendukung penelitian terdahulu oleh Hardono, Haryono dan Yusuf (2017) yang menunjukkan bahwa terdapat pengaruh positif dan signifikan supervisi akademik terhadap kinerja guru. Dalam penelitian tersebut menegaskan bahwa supervisi akademik yang baik akan meningkatkan kinerja guru, karena sebagai kepala sekolah harus mampu menjalankan supervisi akademik untuk memberikan arahan bimbingan dan pengawasan terkait proses pembelajaran sehingga mampu meningkatkan kinerja guru.

Hasil penelitian Aprida, Fitria, dan Nurkhalis (2020) menyatakan bahwa terdapat pengaruh yang positif dan signifikan supervisi akademik terhadap kinerja guru, hal tersebut menunjukkan bahwa semakin baik supervisi akademik semakin baik pula kinerja guru begitu juga sebaliknya semakin rendah supervisi akademik maka semakin kurang baik kinerja guru.

\section{Pengaruh Motivasi Kerja Guru terhadap Kinerja Guru}

Kurniadin dan Machali (2013) menjelaskan bahwa "motivasi dapat memacu seseorang bekerja keras sehingga dapat mencapai tujuan mereka. Motivasi dapat meningkatkan produktivitas kerja sehingga berpengaruh pada pencapaian tujuan individu, kelompok, maupun organisasi”. Selanjutnya Mulyasa (2015) menyatakan "motivasi merupakan salah satu faktor yang turut menentukan keefektifan kerja". Berdasarkan teori tersebut menunjukkan bahwa motivasi kerja mempengarui kinerja guru, dan teori tersebut mendukung hasil penelitian ini. Berdasarkan hasil alaisis regresi pada Tabel ANOVA dalam kolom sig. diperoleh nilai signifikansi sebesar 0,000. Hal ini menunjukkan bahwa H0 ditolak dan Ha diterima. Karena nilai signifikansi lebih kecil dari 0,05 yaitu 0,000. Dari hasil tersebut, dapat disimpulkan bahwa ada pengaruh yang signifikan antara motivasi kerja guru terhadap kinerja guru SD se- Kecamatan Pejagoan Kabupaten Kebumen.

Hasil penelitian ini mendukung penelitian sebelumnya dari Riastuti (2017) yang menyatakan bahawa terdapat pengaruh positif dan signifikan antara motivasi kerja terhadap kinerja guru yang berarti bahwa apabila motivasi kerja semakin tinggi makan kinerja guru juga semakin tinggi. Penelitian lain yang mendukung penelitian ini adalah penelitian dari Diana, Ahmad, dan Wahidy (2020), bahwa didalam penelitian menunjukkan bahwa terdapat pengaruf positif dan signifikan anatara motivasi kerja terhadap kinerja guru, dalam penelitian tersebut menunjukkan bahwa semakin tinggi motivasi kerja guru maka akan semain tinggi kinerja guru, karena semakin bersemangat dalam melaksanakan tugas guru maka akan menghasilan performa kerja yang bagus.

\section{Pengaruh Supervisi Akademik dan Motivasi terhadap Kinerja Guru}

Berdasarkan hasil analisis regresi pada Tabel ANOVA dalam kolom sig. diperoleh nilai signifikansi sebesar 0,000. Hal ini menunjukkan bahwa H0 ditolak dan Ha diterima. Karena nilai signifikansi lebih kecil 
dari 0,05 yaitu 0,000. Dari hasil tersebut, dapat disimpulkan bahwa ada pengaruh yang signifikan antara supervisi akademik dan motivasi kerja guru terhadap kinerja guru SD se- Kecamatan Pejagoan Kabupaten Kebumen. Hasil penelitian mendukung penelitian sebelumnya dari Riastuti (2017) dimana hasil penelitian menunjukkan bahwa terdapat pengaruh antara supervisi akademik dan motivasi kerja terhadap kinerja guru secara Bersama-sama yang berarti apabila supervisi pengawas sekolah semakin sering dilakukan dan motivasi guru semakin tinggi maka kinerja guru akan semakin baik. Penelitian lain yang mendukun adalah penelitian dari Hardono, Haryono dan Yusuf (2017) yang menyatakan bahwa terdapat pengaruh positif dan signifikan antara supervisi akademik dan motivasi kerja terhadap kinerja guru, dimana semakin tinggi supervisi akademik dan motivasi kerja maka akan semakin tinggi kinerja guru begitu juga sebaliknya semakin rendah supervisi akademik dan motivasi kerja maka akan semakin rendah kinerja guru.

Teori lain yang mendukung penelitian ini adalah teori Usman (2008) menyatakan bahwa motivasi kerja dapat diartikan sebagai keinginan atau kebutuhan yang melatarbelakangi seseorang sehingga ia terdorong untuk bekerja. Seseorang dapat bergairah dan bekerja keras jika mampu membangkitkan motivasi untuk bekerja keras sehingga dapat tujuan dpat tercapai. Motivasi menjadi salah satu faktor dominan dalam meningkatkan produktivitas kerja, sehingga berpengaruh pada pencapaian tujuan individu, kelompok, maupun organisasi. Tingginya motivasi kerja yang memiliki guru akan mendorong dan terus meningkatkan kemampuan dirinya untuk memenuhi kebutuhan dan mencapai tujuan yang diinginkan dalam bekerja.

\section{KESIMPULAN}

Berdasarkan hasil penelitian dan pembahasan, beberapa simpulan sebagai berikut: (1) terdapat pengaruh positif supervisi akademik terhadap kinerja guru. Terbukti dari uji regresi berdasarkan Tabel ANOVA pada kolom sig. diperoleh nilai signifikansi sebesar 0,000 lebih kecil dari 0,05. Hal ini menunjukkan bahwa H0 ditolak dan Ha diterima; (2) terdapat pengaruh positif motivasi kerja guru terhadap kinerja guru. Terbukti dari hasil uji regresi berdasarkan Tabel ANOVA pada kolom sig. diperoleh nilai signifikansi sebesar 0,000 lebih kecil dari 0,05. Hal ini menunjukkan bahwa H0 ditolak dan Ha diterima; (3) terjadi pengaruh yang kuat antara supervisi akademik dan motivasi kerja guru terhadap kinerja guru. Terbukti dari hasil uji regresi berdasarkan Tabel ANOVA pada kolom sig. diperoleh nilai signifikansi sebesar 0,000 lebih kecil dari 0,05. Hal ini menunjukkan bahwa H0 ditolak dan Ha diterima.

\section{UCAPAN TERIMA KASIH}

Terima kasih saya ucapakan kepada keluarga, dosen pembimbing yang telah membimbing dan memberikan ilmu yang sangat bermanfaat demi penyelesaian TAPM ini, rekan-rekan mahasiswa Prodi Magister Pendidikan Dasar Universitas Terbuka, seluruh dosen dan staff UPBJJ UT Purwokerto yang telah membantu peneliti dalam menyelesaikan penelitian ini.

\section{DAFTAR PUSTAKA}

Aprida, Y., Fitria, H., \& Nurkhalis, N. (2020). Pengaruh Supervisi Kepala Sekolah Dan Motivasi Kerja Guru Terhadap Kinerja Guru. Journal Of Education Research, 1(2), 160-164.

Diana, R., Ahmad, S., \& Wahidy, A. (2020). Pengaruh Motivasi Kerja Dan Komunikasi Interpersonal Terhadap Kinerja Guru. Jurnal Pendidikan Tambusai, 4(3), 1828-1835.

Gusti, M. M. (2012). Pengaruh Kedisiplinan, Motivasi Kerja, Dan Persepsi Guru Tentang Kepemimpinan Kepala Sekolah Terhadap Kinerja Guru Smkn 1 Purworejo Pasca Sertifikasi. UNY. 
2007 Pengaruh Pelaksanaan Supervisi Akademik dan Motivasi Kerja Guru terhadap Kinerja Guru Sekolah Dasar - Wardatul Adibah, Suhartono, Rais Hidayat

DOI: https://doi.org/10.31004/edukatif.v3i4.1049

Hardono, H., Haryono, H., \& Yusuf, A. (2017). Kepemimpinan Kepala Sekolah, Supervisi Akademik, Dan Motivasi Kerja Dalam Meningkatkan Kinerja Guru. Educational Management, 6(1), 26-33.

Kurniadin, D., Machali, I., \& Sandra, M. (2013). Manajemen Pendidikan: Konsep \& Prinsip Pengelolaan Pendidikan. Ar-Ruzz Media.

Mulyasa, E. (2015). Menjadi Guru Profesional, Menciptakan Pembelajaran Kreatif Dan Menyenangkan. PT. Remaja Rosdakarya.

Muslich, M. (2011). Pendidikan Karakter Menjawab Tantangan Krisis Multidimensional. Bumi Aksara.

Riastuti, D. (2017). Pengaruh Supervisi Akademik Dan Motivasi Kerja Guru PAI Terhadap Kinerja Guru Pai Di Sekolah Dasar Negeri Kabupaten Sukoharjo Tahun 2017. Tesis.

Rismawan, E. (2015). Pengaruh Supervisi Kepala Sekolah Dan Motivasi Berprestasi Guru Terhadap Kinerja Mengajar Guru. Jurnal Administrasi Pendidikan, 22(1).

Sugiyono. (2017). Metode Penelitian Pendidikan:(Pendekatan Kuantitatif, Kualitatif Dan $R \&$ D). Alfabeta.

Usman, H., \& Akbar, P. S. (2008). Metodologi Penelitian Sosial. Bumi Aksara. 